\title{
Situation of Vegetable Cultivation in the Khulna Region of Bangladesh Due To Climate Change and Shrimp Farming
}

\author{
M Abdul Mannan* and Maudur Rahman \\ Department of Agrotechnology Discipline, Khulna University, Bangladesh
}

Submission: May 19, 2017; Published: June 02, 2017

*Corresponding author: M Abdul Mannan, Professor, Agrotechnology Discipline, Khulna University, Khulna-9208, Bangladesh, Email: mannanku@gmail.com

\begin{abstract}
The main purposes of the study were to determine the present situation of vegetable cultivation due to shrimp farming and climate change. Data were collected from randomly selected 120 vegetable growers of three selected Upazilla under Khulna district through personal interview method by using an interview schedule during October 2012 to July 2013. Data were collected on total cultivable land, land suitable for vegetable cultivation, land under vegetable cultivation, and types of vegetable cultivated, use of fertilizers and manures, diseases and insect infestation, intercultural operations, experience in agriculture, experience in vegetable cultivation and knowledge in vegetable cultivation to determine the situation of vegetable cultivation. Besides, data were collected on eleven selected characteristics of the vegetable growers and the problems confronted by them. Most of respondents had medium to high experience in agriculture and vegetable cultivation and they belonged to medium knowledge category in cultivation of vegetable.
\end{abstract}

Most of the respondents had small to moderate sized cultivable lands. Majority of the respondents had small to moderately large sized lands suitable for vegetable cultivation. Bean, cauliflower, cabbage, potato, Indian spinach, brinjal were more extensively cultivated. Most of the respondents use cow dung, urea, TSP and MoP in vegetable cultivation. Viral disease was the most occurring disease in vegetables cultivation. Leaf cutting caterpillar was most commonly occurring insect. A number of problems were identified in vegetable cultivation faced by the farmers in the study area. Among the 19 confronted problems unavailability of good quality seed, salinity, diseases and insect infestation were some of the major problems. Among the 10 selected characteristics of the respondents only cosmopoliteness and knowledge of vegetable cultivation showed a negative significant relationship.

Among the selected 10 causes of changing of choosing vegetables, the most important was introduction of prawn culture for prawn farming area, increase of high demand of vegetables for non-prawn farming area, increase of salinity for shrimp farming area and non-shrimp farming area. There was a trend to increase in the total number of cropping patterns from 1980s to 2013 and showed a distinct figure of changing vegetables cropping patterns at different years. Among the selected 9 causes of changing vegetables cropping patterns, the most important was introduction of prawn farming for prawn farming area, increase of vegetables yield in a unit area for non-prawn farming area, increase of salinity for shrimp farming area and natural calamities for non-shrimp farming area.

Keywords: Vegetables; Khulna; Bangladesh; Climate change; Shrimp farming

\section{Introduction}

As a developing country, Bangladesh is adequately suffering from the problems of poverty, unemployment and malnutrition. Vegetable sub-sector can play important role to solve these problems in the shortest possible time. The importance of vegetable can be realized from two stand points such as, economic and nutritional point of view. It creates a great opportunity of employment for the large number of unemployed women of Bangladesh
In Bangladesh a good number of vegetables grown throughout the year, in view of increase the income of population and nutritional considerations there is a great need for vegetable production. Farmers used to grow vegetables in and around the homestead area but nowa-days a large number of farmers grow vegetable on commercial scale because vegetable cultivation is more profitable than that of cereal crops. The weather, climate and soil of Bangladesh are very much suitable for growing vegetable round the year. 
Introduction of prawn farming opens a new dimension in case of vegetables production even in low land i.e. gher's ail. The gher farming technology was developed in the 1980s by farmers in Bagerhat district. Since then gher farming has spread rapidly to other districts: Khulna, Jessore, Gopalganj and Satkhira, and the number of ghers increases by approximately 10-20 percent every year [1-3]. Gher farming is now the primary livelihood strategy of more than 100,000 rural households in the south-west of Bangladesh. Gher farming has brought about dramatic changes in the society as well as to the institutions that govern the local and the regional economy. Shrimp farming also adversely affects agricultural production. Increasing the intensity of saline in soil is bad alarming for vegetable cultivation. Climate change is defined as any change in global temperatures and precipitation over a period of time due to natural variability or as a result of human activity. It is the mother of all environmental changes [4].

Changes in the world's climate will bring major shifts in food production [5]. In some places, temperatures will rise and rainfall will increase; in others, rainfall will decrease. In addition, coastal flooding will reduce the amount of land available for agriculture [6]. In general, food crops are sensitive to climate change. Such change, which affects soil temperature and moisture levels, also determines the vitality of both beneficial organisms and pests. Due to the enormous uncertainties surrounding global climate change, estimates of cropland reductions vary widely from 10 to 50 percent (Stevens, 1989)

In cultivation of vegetable farmers face many problems. Considering the nature of study the researcher sought information regarding following research questions.

I. What is the present situation of vegetable cultivation?

II. What are the problems being faced by the farmers in cultivation of vegetables?

III. What are the personal, social, economic and psychological characteristics of the vegetables growers?

IV. What is the past and present vegetable cropping pattern?

V. What is the main cause of changing vegetable cropping pattern?

To make cultivation of vegetables profitable it is necessary to involve farmers' in production, planning and ascertain problem with regard to vegetables production. To identification of the present condition of malnutrition of the people, find out the way of increasing production of vegetables by identifying main problems of vegetables cultivation, if there exist any change of vegetable cropping pattern due to climate change and shrimp farming, farmer benefited or not from such kind of change etc. are the main justifications of the study. Due to climate change, temperature of the world is increasing. As a result of global warming, sea level is rising as ice is melting continuously. Due to the rise in sea level, salinity of water is uprising. For anyhow, if this saline water enters into the crop field, it rapidly affects the crop production negatively. Because of natural calamity, sea water is going into the cultivated land through the channel of river. The frequency of natural calamity like flood, drought, water logging, and inundation of saline water are occurring due to climate change. It is causing the damage of sensitive embankments of rivers. Thus hampering of crop field and eventually the living places with a surge has become a common phenomenon in the coastal area.

The present study makes attempt to have an understanding of present situation of vegetable cultivation and problems faced by the farmers in cultivation of vegetables and explore its relationship with their selected characteristics. The present study also makes attempt to have an identification of different cropping pattern and the causes of changing vegetable cropping pattern. The findings of this study will be particularly applicable to the farmers or the respective study area. The findings may also have applicability to other areas of the country where the physical, socio-economic and cultural conditions are mostly similar with those of the study area. However, the findings of the study will be helpful for the specialist of different organizations and planners, policy makers and extension agents in removing constraints faced by the farmers in cultivation of vegetable. The administrators, supervisors, field workers and others who are to work in the field of vegetable production may find this study informative. This study could be helpful for vegetable cultivation programme in one hand and motivate consume to cultivate more vegetables and earn more foreign exchange on the other.

In view of the consideration of above stated research questions the following specific objectives have been formulated for giving proper direction to the study:

a. To determine the present situation of vegetable cultivation.

b. To identify vegetables cropping pattern and causes of changing vegetables cropping pattern.

\section{Methodology}

This study was a survey based research. The study was confined to three upazilas (Dumuria, Paikgachha and Koyra) of Khulna district. Khulna, the south-western divisional city in Bangladesh, is situated between 21.38' and 23.1' north latitude and 88.58' east longitude and is $12 \mathrm{ft}$ above mean sea level (http://www.khulnacity.org/).

This study was conducted into 4 types of areas such as prawn farming area, non-prawn farming area (non-saline zone) and shrimp farming area and non- shrimp farming area (saline zone).

\section{Distribution of study area (Table 1)}

Table 1: Distribution of study area.

\begin{tabular}{|c|c|c|c|}
\hline \multirow{2}{*}{ District } & Upazila & $\begin{array}{c}\text { Types } \\
\text { of Area }\end{array}$ & Union \\
\hline \multirow{2}{*}{ Khulna } & Dumuria & PFA & Dhamalia, Rudaghara Rgunathpur \\
\cline { 3 - 4 } & Paikgachha & SFA & Kharnia, Atlia, Shobna \\
\cline { 2 - 4 } & Koyra & NSFA & $\begin{array}{c}\text { Gadaripur, Raruli } \\
\text { Chandkhali }\end{array}$ \\
\cline { 2 - 4 } & & $\begin{array}{c}\text { Uttar Bedkashi, Moharajpur } \\
\text { Bagali }\end{array}$ \\
\hline
\end{tabular}


FA: Prawn Farming Area; NPFA: Non-Prawn Farming Area; SFA: Shrimp Farming Area; NSFA: Non-Shrimp Farming Area

\section{Unit of Analysis}

The unit of analysis of the study was the farm households of four selected different areas. The major criteria considered for selection of farm households from the study area were:

a. The farmers of these farm households were cultivators of vegetables

b. They were cultivating vegetables to fulfill their own demand and their economic development

c. The farmers of the selected study area particularly who are about 40 years old and involved in Prawn/shrimp farming in case of prawn farming area and shrimp farming area.

\section{Population and sampling}

The vegetables cultivators of the selected areas were treated as population of the study. Following the random sampling method, irrespective of population size 10 vegetables growers were selected from each of the mentioned union. Thus the final sample size stood 120.

\section{Sampling Design (Table 2)}

Table 2: Sampling Design.

\begin{tabular}{|c|c|c|c|c|}
\hline \multicolumn{3}{|c|}{ Study area } & $\begin{array}{l}\text { Number of } \\
\text { sampled } \\
\text { farmers }\end{array}$ & $\begin{array}{c}\text { Total } \\
\text { sampled } \\
\text { farmers }\end{array}$ \\
\hline \multicolumn{3}{|c|}{ Khulna District } & & \\
\hline Upazila & & Union & & \\
\hline \multirow{6}{*}{ Dumuria } & \multirow{3}{*}{$\begin{array}{c}\text { Prawn } \\
\text { farming } \\
\text { area }\end{array}$} & Dhamalia & 10 & \multirow{3}{*}{30} \\
\hline & & Rudaghara & & \\
\hline & & Rgunathpur & & \\
\hline & \multirow{3}{*}{$\begin{array}{l}\text { Non-prawn } \\
\text { farming } \\
\text { area }\end{array}$} & Kharnia & 10 & \multirow{3}{*}{30} \\
\hline & & Atlia & 10 & \\
\hline & & Shobna & 10 & \\
\hline \multirow{3}{*}{ Paikgachha } & \multirow{3}{*}{$\begin{array}{l}\text { Shrimp } \\
\text { farming } \\
\text { area }\end{array}$} & Gadaripur & 10 & \multirow{3}{*}{30} \\
\hline & & Raruli & 10 & \\
\hline & & Chandkhali & 10 & \\
\hline \multirow{3}{*}{ Koyra } & \multirow{3}{*}{$\begin{array}{l}\text { Non- } \\
\text { shrimp } \\
\text { farming } \\
\text { area }\end{array}$} & $\begin{array}{c}\text { Uttar } \\
\text { Bedkashi }\end{array}$ & 10 & \multirow{3}{*}{30} \\
\hline & & Moharajpur & 10 & \\
\hline & & Bagali & 10 & \\
\hline \multicolumn{4}{|c|}{ Total } & 120 \\
\hline
\end{tabular}

\section{Instrument for data collection}

An interview schedule was used as the research instrument in order to collect relevant information from the respondents. The interview schedule was carefully designed keeping the objectives of the study in mind. The interview schedule was prepared for data collection in Bengali keeping the objectives of the study in view. The interview schedule contained both open and close ended, simple and direct form of questions to collect data on the selected variables.
After preparation of interview schedule it was pre-tested with 10 farmers of Rudaghara union. After pre-test, necessary correction, addition, alternation and rearrangement were made before it was run for final data collection. The interview schedule was then multiplied in its final form for collection of data. English version of the same interview schedule may be seen at Appendix 1.

\section{Data Collection}

Data for this study were collected by the researcher himself through face to face interview by using interview schedule during October 2012 to July 2013. Before going to make an interview, appointments with the interviewees were made in advance with the help of the concerned Sub Assistant Agriculture Officer (SAAO). All possible efforts were made to explain the purpose of the study to the respondents in order to get valid and pertinent information from them. The farmers of the selected areas helped investigator greatly in collecting information. The researcher also obtained cooperation from the members of the union parished of the respective villages, local leaders and school teachers during collection of data.

\section{Specification and Measurement of the Variables}

A variable is any characteristic, which can assume varying or different values in successive individual cases [7]. A well organized piece of research usually contains at least two important elements, viz. an independent variable and a dependent variable. An independent variable is that variable which is manipulated by the researcher in his attempt to ascertain its relationships to an observed phenomenon. A dependent variable is that variable is that variable which appears, disappears or varies as the researcher introduces, removes or varies the independent variables. In this connection, the researcher reviewed literature to widen his understanding about the nature and scope of the variables relevant to this piece of research.

\section{Specification and Measurement of Independent Variables}

Based on the practical knowledge, side by side an extensive review of literature and discussions with relevant experts and academicians, the researcher selected 10 characteristics of the respondents. The characteristics of respondents which were treated as independent variables for the study are age, education, family size, experience in agriculture, experience in vegetable cultivation, annual income, organizational participation, cosmopoliteness, extension media contact, training exposure and knowledge in vegetable cultivation. On the basis of definition of the terms presented in earlier sections, operationalization of the variables was done which are presented below.

\section{Data Processing and Analysis}

Collected data were compiled, coded, tabulated for processing and analysis in accordance with the objectives of the study. For arriving at a meaningful conclusion, tabular presentation of data was intensively used. The SPSS IBM-20 computer package program was used to analyze the data. Descriptive statistics like number, percentage, range, mean and standard deviation were used in describing selected independent variables of the study. 


\section{Psychology and Behavioral Science International Journal}

\section{Results and Discussion}

The age of the respondents ranged from 30-78 with a mean and standard deviation of 48.18 years and 46.00 , respectively. The majority (62.5\%) of the respondents belonged to middle age category as compared to old (22.5\%) and young (15\%). The education scores of the respondents ranged from 0-17 with a mean and standard deviation of 7.53 years and 4.60 , respectively. The highest proportion
(37.5\%) of the respondents possessed secondary level of education followed by primary education (35\%), higher education (11.7\%) and higher secondary education $(10.8 \%)$. The family size of the respondents ranged from 2-10 with a mean and standard deviation of 4.22 and 1.02, respectively. The majority (65.0\%) of the farmers had small sized family as compared to medium (34.2\%) and large $(0.8 \%)$ sized family (Table 3 ).

Table 3: Distribution of respondents according to their selected characteristics.

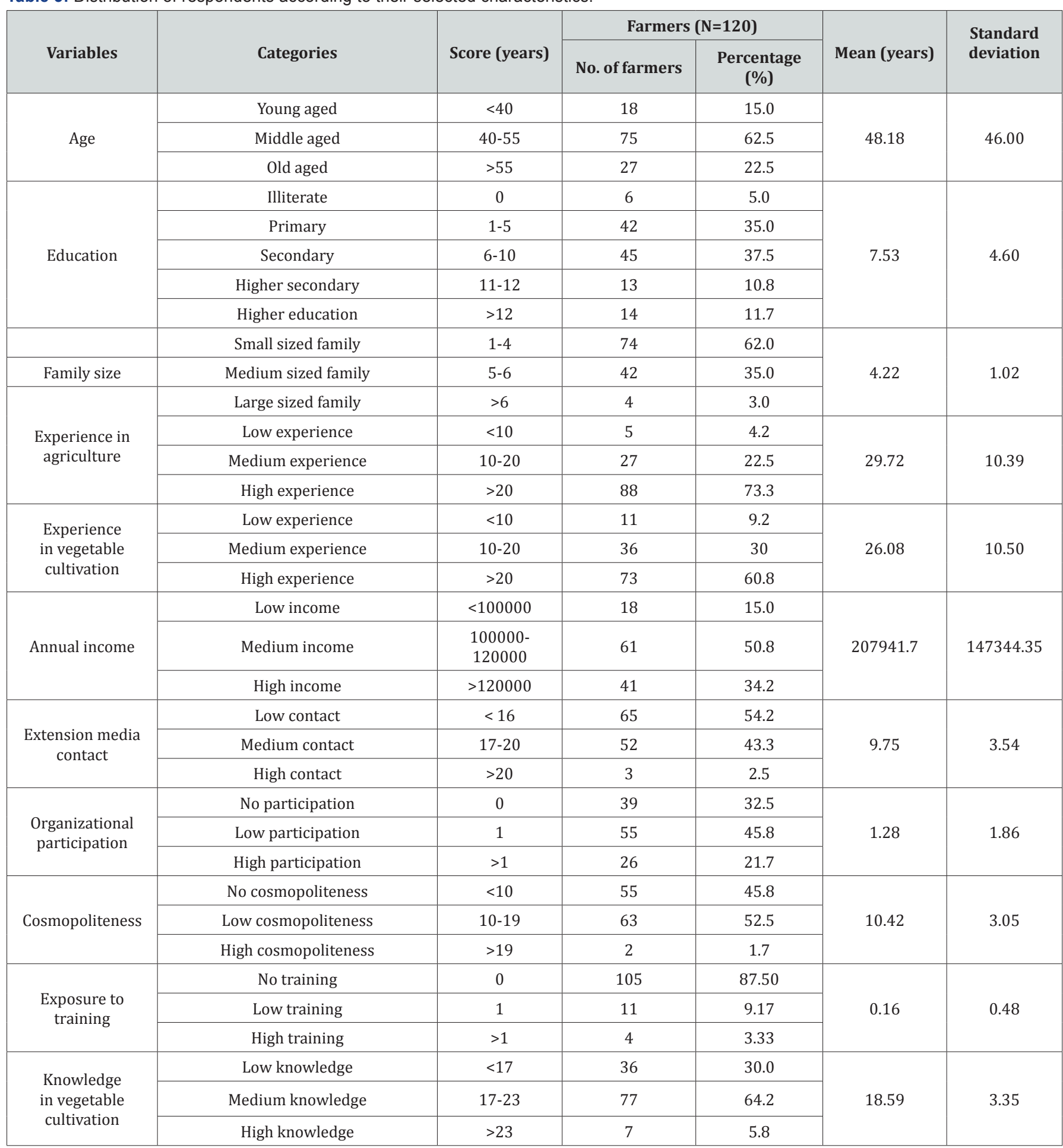


The scores on experience in agriculture of the farmers ranged from 10-66 years with mean of 29.72 years and standard deviation of 10.39. It was found that the most (73.3\%) of the respondents had high experienced and a very few (4.2\%) respondents was low experienced. And the rest $(22.5 \%)$ of the respondents was medium experienced (Table 3). The scores on experience in vegetable cultivation of the farmers ranged from 2- 66 years with mean and standard deviation of 26.08 years and 10.50 , respectively. It was found that the majority of the farmers $(60 \%)$ had high experienced, followed by medium (30\%) and low (9.24\%) experience. The annual income (from nonagricultural + agricultural sources) of the farmers ranged from 70 thousand taka to 1150 thousand taka with the mean and standard deviation of 207941.7 taka and 147344.35 , respectively. More than half $(50.08 \%)$ of the respondents belonged to medium income group followed by (34.2\%) high income and $15 \%$ of respondents was low income categories (Table 3).

Respondents use various information sources and media to a different extent in order to receive agricultural information. Extension media contact scores of the respondents ranged from 2 - 26, with an average of 9.75 and standard deviation of 3.54. The majority of the respondents (54.2\%) had low contact as compared to medium contact (43.3\%) and had high contact (2.5\%). 5.1.8 The organizational participation scores of the respondents ranged from 0-12 with a mean and standard deviation of 1.28 and 1.86 , respectively. Low participation was observed for majority (45.8\%) of the respondents and about one-fifth (21.7\%) of the farmers had high medium participation in different organization while $32.5 \%$ of the respondents had no organizational participation (Table 3 ).

\section{Present situation of vegetable cultivation}

Table 4: Distribution of respondents according to their total cultivable land.

\begin{tabular}{|c|c|c|c|c|c|c|c|c|c|}
\hline \multirow{3}{*}{ Categories } & \multirow{3}{*}{ Score (ha) } & \multicolumn{8}{|c|}{ Respondents } \\
\hline & & \multicolumn{2}{|c|}{ PFA } & \multicolumn{2}{|c|}{ NPFA } & \multicolumn{2}{|c|}{ SFA } & \multicolumn{2}{|c|}{ NSFA } \\
\hline & & No. & $\%$ & No. & $\%$ & No. & $\%$ & No. & $\%$ \\
\hline Small & $<0.10$ & 12 & 40.0 & 7 & 23.33 & 8 & 26.7 & 10 & 33.3 \\
\hline Moderate & $0.10-0.20$ & 10 & 33.3 & 9 & 30.00 & 6 & 20.0 & 8 & 26.7 \\
\hline $\begin{array}{c}\text { Moderately } \\
\text { large }\end{array}$ & $0.21-0.40$ & 7 & 23.3 & 8 & 26.67 & 9 & 30.0 & 9 & 30.0 \\
\hline Large & $>0.40$ & 1 & 3.33 & 6 & 20.00 & 7 & 23.3 & 3 & 10.0 \\
\hline
\end{tabular}

PFA: Prawn Farming Area; NPFA: Non-Prawn Farming Area; SFA: Shrimp Farming Area; NSFA: Non-Shrimp Farming Area
The total cultivable land in shrimp farming area ranged from $0.06-4.10$ ha with mean and standard deviation of 1.03 ha and 0.94 , respectively while it was $0.04-2.27,0.53$ ha and 0.47 for the same in case of non-shrimp farming area (Table 4). Majority (60\%) of the respondents in shrimp farming area had moderately large to large amount of cultivable land while more than three-fourths of the respondents $(76.6 \%)$ in non shrimp farming area had small to moderate amount of cultivable land. But most of the respondents of prawn farming area (76.7\%) and non-prawn farming area (90\%) possessed small to moderate amount of cultivable land (Table 4).
The cosmopoliteness scores of the respondents ranged from 6-23 with a mean and standard deviation of 10.42 and 3.05, respectively. The majority (52.5\%) of the respondents had low cosmopoliteness. Only $1.7 \%$ of the respondents are highly cosmopolite while $45.8 \%$ of the respondents had no cosmopoliteness. The scores of training exposure of the respondents ranged from 0 - 2 with an average of 0.16 and standard deviation of 0.48 . Most of the respondents $(87.50 \%)$ had no training followed by low training $(9.17 \%)$ and $3.33 \%$ respondents had high training (Table 3 ). The knowledge in vegetable cultivation scores of the respondents ranged from 10-30 with a mean and standard deviation of 18.59 and 3.35, respectively. Majority (64.2\%) of the respondents belonged to medium knowledge group, while about $30 \%$ of respondents had low knowledge and 5.8\% had high knowledge in vegetable cultivation.

\section{Problem Confrontation of Vegetable cultivation}

Among the confronted problems unavailability of good quality seed, salinity, diseases and insect infestation were some of the major problem. On the other hand, lack of protection, lack of loan facilities, high production cost, scarcity of quality fertilizer were some of the less severe problems. The score of problem confrontation ranged from 3-40 with a mean of 19.23 and having standard deviation of 6.86. Majority (60\%) of the respondents confronted low problem. Only $8.3 \%$ of the respondents confronted high problem while $31.7 \%$ of the respondents confronted medium problem. Among the 11 selected characteristics of the respondents, only two characteristics such as, cosmopoliteness and knowledge of vegetable cultivation showed a negative but significant relationship. The negative trend of relationships implies that the lower is the cosmopoliteness and knowledge of vegetable cultivation of the respondents the higher is the problem confrontation in vegetable cultivation.
The total suitable land for vegetable cultivation in non-prawn farming area ranged from $0.04-0.81$ ha with mean and standard deviation of 0.24 ha and 0.19 , respectively while it was $0.02-1.54$, 0.22 ha and 0.37 for the same in case of shrimp farming area. About three-fourths of the respondents (73.3\%) in prawn farming area had small to moderate amount of suitable land while in case of nonshrimp farming area that was $60 \%$. But more than fifty percent of the respondents of non-prawn farming area (56.67\%) possessed moderate to moderately large and shrimp farming area (53.3\%) possessed moderately large to large amount of suitable land for vegetable cultivation (Table 5). 


\section{Psychology and Behavioral Science International Journal}

Table 5: Distribution of respondents according to their suitable land for vegetable cultivation.

\begin{tabular}{|c|c|c|c|c|c|c|c|c|c|}
\hline \multirow{3}{*}{ Categories } & \multirow{3}{*}{ Score (ha) } & \multicolumn{8}{|c|}{ Respondents } \\
\hline & & \multicolumn{2}{|c|}{ PFA } & \multicolumn{2}{|c|}{ NPFA } & \multicolumn{2}{|c|}{ SFA } & \multicolumn{2}{|c|}{ NSFA } \\
\hline & & No. & $\%$ & No. & $\%$ & No. & $\%$ & No. & $\%$ \\
\hline Small & $<0.10$ & 16 & 53.3 & 9 & 30.0 & 10 & 33.3 & 18 & 60.0 \\
\hline Moderate & $0.10-0.20$ & 10 & 33.3 & 10 & 33.3 & 9 & 30.0 & 6 & 20.0 \\
\hline $\begin{array}{l}\text { Moderately } \\
\text { large }\end{array}$ & $0.21-0.40$ & 4 & 13.3 & 8 & 26.7 & 6 & 20.0 & 6 & 20.0 \\
\hline Large & $>0.40$ & 0 & 0.0 & 3 & 10.0 & 5 & 16.7 & 0 & 0 \\
\hline Total & & 30 & 100 & 30 & 100 & 30 & 100 & 30 & 100 \\
\hline
\end{tabular}

PFA: Prawn Farming Area; NPFA: Non-Prawn Farming Area; SFA: Shrimp Farming Area; NSFA: Non-Shrimp Farming Area

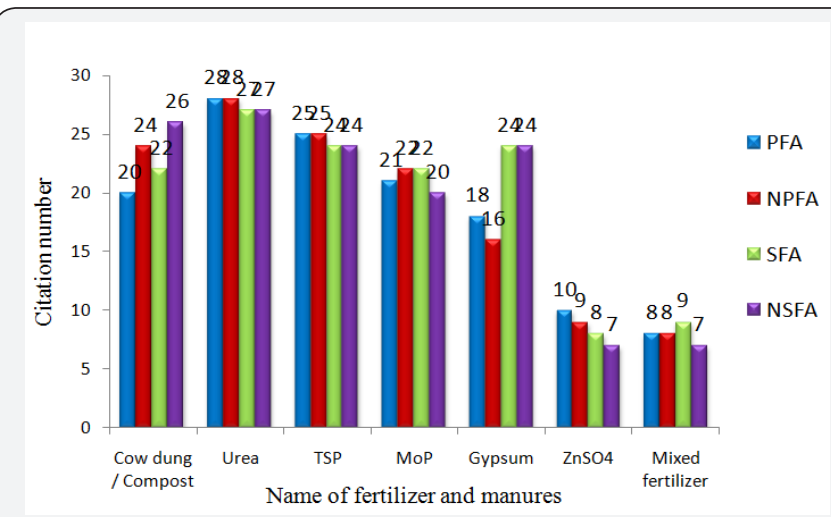

Figure 1: Use of fertilizers and manures by respondents in their farm.

PFA: Prawn Farming Area; NPFA: Non-Prawn Farming Area; SFA: Shrimp Farming Area; NSFA: Non-Shrimp Farming Area

The land under vegetable cultivation in non-prawn farming area ranged from $0.04-0.40$ ha with mean and standard deviation of 0.18 ha and 0.11 , respectively while it was $0.02-0.86,0.16$ ha and 0.15 for the same in case of shrimp farming area. Most of the respondents of prawn farming area $(86.6 \%)$, non-shrimp farming area $(80.0 \%)$, shrimp farming area $(63.3 \%)$ and non-prawn farming area $(66.3 \%)$ possessed small to moderate amount of land under vegetable cultivate. It was revealed that $93.33 \%$ respondents used urea in both prawn farming area and non-prawn farming area while 90\% respondents used urea in both shrimp farming area and nonshrimp farming area. $80 \%$ respondents used gypsum in both shrimp farming area and non-shrimp farming area while that was only $60 \%$ respondents in prawn farming area and $53.33 \%$ respondents in nonprawn farming area (Figure 1).

Table 6: Intercultural operations perform by the respondents in their farm.

\begin{tabular}{|c|c|c|c|c|c|c|c|c|}
\hline \multirow{3}{*}{$\begin{array}{l}\text { Name of } \\
\text { operation }\end{array}$} & \multicolumn{8}{|c|}{ Citation number } \\
\hline & PFA & & NPFA & & SFA & & NSFA & \\
\hline & No. & $\%$ & No. & $\%$ & No. & $\%$ & No. & $\%$ \\
\hline Weeding & 27 & 90.00 & 28 & 93.33 & 25 & 83.33 & 26 & 86.67 \\
\hline Irrigation & 26 & 86.67 & 28 & 93.33 & 26 & 86.67 & 26 & 86.67 \\
\hline Earthing up & 18 & 60.00 & 14 & 46.67 & 13 & 43.33 & 15 & 50.00 \\
\hline Thinning & 14 & 46.67 & 21 & 70.00 & 15 & 50.00 & 22 & 73.33 \\
\hline Mulching & 2 & 6.67 & 4 & 13.33 & 1 & 3.33 & 5 & 16.67 \\
\hline Staking & 12 & 40.00 & 14 & 46.67 & 12 & 40.00 & 12 & 40.00 \\
\hline Slacking & 10 & 33.33 & 8 & 26.67 & 9 & 30.00 & 5 & 16.67 \\
\hline
\end{tabular}

PFA: Prawn Farming Area; NPFA: Non-Prawn Farming Area; SFA: Shrimp Farming Area; NSFA: Non-Shrimp Farming Area

It was revealed that most of the respondents (86.67\%-93.33\%) were practiced weeding and irrigation in all types of study area. A good percentage of respondents (40.00\%-73.3300\%) followed earthing up, thinning and staking in their field (Table 6).

Among the 30 respondents, highest proportion (23, 20, 11, 10 and 6) of the respondents cited that their plants were affected by viral diseases, leaf spot of cabbage \& cauliflower, powdery mildew of cucurbits, early blight of potato \& tomato and little leaf of brinjal, respectively in non-shrimp area while $(15,12,11,10$ and 7) respondents cited that their plants were affected by mosaic of okra \& tomato, late blight of potato \& tomato, anthracnose of bean
\& cucurbits, early blight of potato \& tomato and wilt of potato \& tomato, respectively in the shrimp farming area (Figure 2).

Among the 30 respondents, highest proportion (18, 18, and 14) of the respondents cited that their plants were infested by potato tuber moth, cutworm of potato fruits and shoot borer of brinjal and okra in non-shrimp farming area while $(14,11$ and 11) of the respondents cited that their plants were infested by leaf cutting caterpillar, fruit and shoot borer of brinjal and okra and red mite in non-shrimp farming area (Figure 3). 


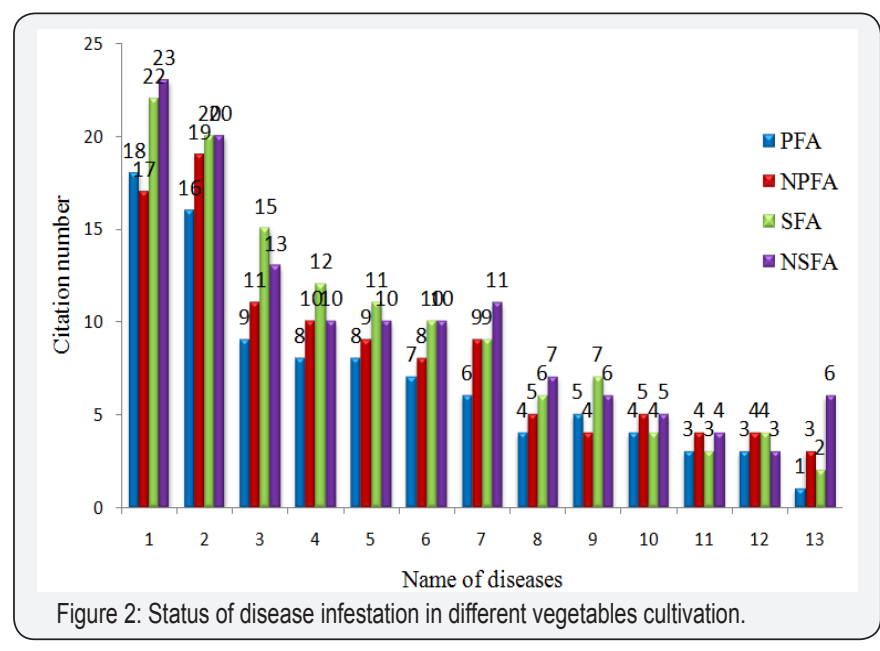

PFA: Prawn Farming Area; NPFA: Non-Prawn Farming Area; SFA Shrimp Farming Area; NSFA: Non-Shrimp Farming Area

$1=$ Viral disease, $2=$ Leaf spot of cabbage \& cauliflower, $3=$ Mosaic of okra \& tomato, $4=$ Late blight of potato \& tomato, $5=$ Anthracnose of bean $\&$ cucurbits, $6=$ Early blight of potato \& tomato, $7=$ Powdery mildew of cucurbits, $8=$ Damping off of potato $\&$ tomato, $9=$ Wilt of potato \& tomato, $10=$ Fruit rot of brinjal, $11=$ Root rot, $12=$ Stem rot $13=$ Little leaf of brinjal

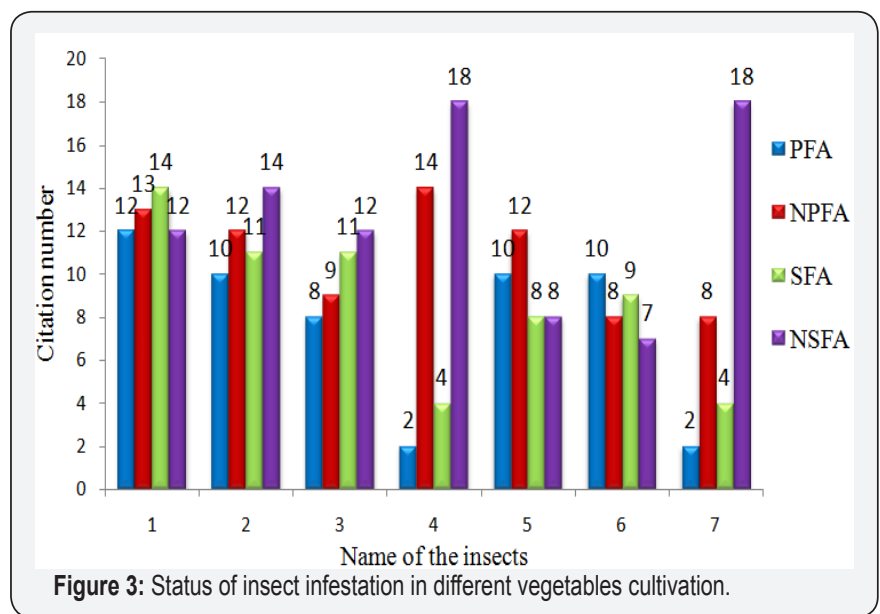

PFA: Prawn Farming Area; NPFA: Non-Prawn Farming Area; SFA Shrimp Farming Area; NSFA: Non-Shrimp Farming Area

$1=$ Leaf cutting caterpillar, $2=$ Fruit $\&$ shoot borer of brinjal \& okra, $3=$ Red mite, $4=$ Cutworm of potato, $5=$ Pumpkin beetle, $6=$ Aphid of bean \& tomato, $7=$ Potato tuber moth

\section{Causes of change in choosing vegetables for cultivation}

In the study area of prawn farming among the 30 respondents, 8 respondents didn't cultivate vegetable before prawn farming In this area, in case of choosing vegetables 20 respondents out of 30 were agreed with the statement of introduction of prawn farming, 16 respondents were agreed with the 3 statements, availability of new varieties, high demand of vegetables and good market price. In the study area of non-prawn farming most of the farmers cultivate vegetable on the basis of commercial purpose since many years mainly in high land and some of medium high land. In case of choosing vegetables 28 respondents out of 30 were agreed with the statement of high demand of vegetables, 27 respondents out of 30 were agreed with the statement of good market price, 26 respondents out of 30 were agreed with the statement of availability of new varieties. 16 respondents were agreed with the statement of the change of food habit (Figure 4).

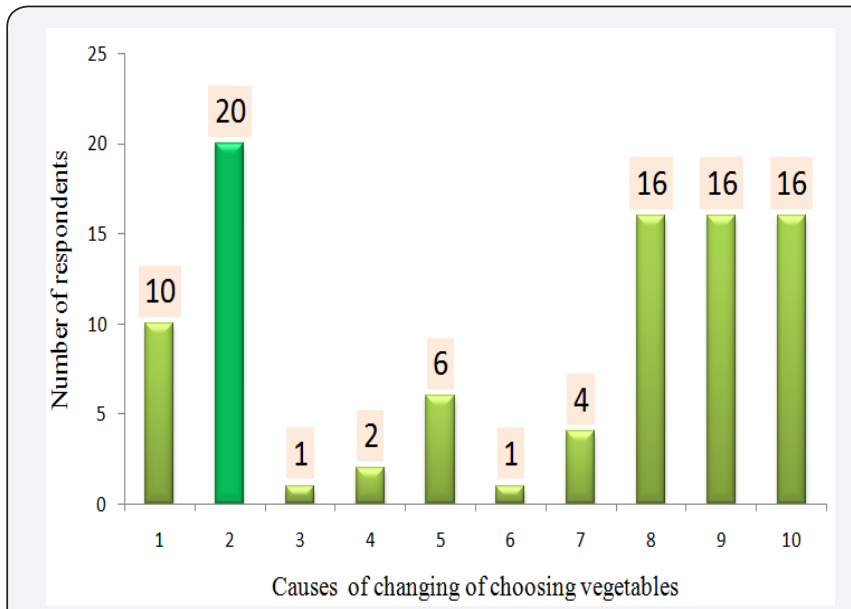

Figure 4: Causes of change in choosing vegetables for cultivation

Note: 1 = Increase of salinity, $2=$ Introduction of prawn farming, $3=$ Excess rainfall, $4=$ Drought, $5=$ Lack of essential irrigation water, 6 $=$ Natural calamities, $7=$ Change of food habit, $8=$ Availability of new variety, $9=$ high demand of vegetables and $10=$ Good market price

In the study area of shrimp farming, salinity problem plays a negative role in case of vegetable production. Most of the farmer cultivates vegetable in high land and some in gher's ail, whereas salinity level is very low. In case of choosing vegetables 25 respondents out of 30 were agreed with the statement of increase of salinity. In case of choosing vegetables 28 respondents out of 30 were agreed with the statement of high demand of vegetables, 27 respondents out of 30 were agreed with the statement of good market price, 26 respondents out of 30 were agreed with the statement of availability of new varieties. In this study area of non-shrimp, mostly vegetable production was done in high land and some in medium high land. In case of choosing vegetables 27 respondents out of 30 were agreed with the statement of increase of salinity, 26 respondents out of 30 were agreed with the statement of natural calamities. High demand of vegetables was cited by 22 respondents as the causes of selected vegetables. Good market price and availability of new varieties were cited by 20 respondents as the causes of selected vegetables. 18 respondents were agreed with the statement of lack of essential irrigation water.

\section{Identification of vegetables cropping pattern in different years}

In the study area of prawn farming in 1980 a total of 6 cropping patterns were practiced. At that time, it was found that single cropped cropping pattern (fallow-aman) was practised in all type of land topography. At that time, among all the respondents (30), fallowaus+aman was noticed to practised by 12 respondents in high land and 10 respondents in medium high land. Fallow-joli aus was noticed by 10 respondents in low land and 8 respondents in medium high land. Fallow-aman was cited by 10, 5 and 2 respondents in low land, 
medium high land and high land, respectively. In 1990s, most of the prawn farming of the study area remained under water around the year and then a dramatically decrease the changing cropping pattern as observed from the study area. As a result only a total of 6 cropping pattern were practised in 1990s. At that time, 30 respondents in low land, 26 respondents in medium high land and 6 respondents in high land were not practiced any crops due to submergence.

About 20 years ago Prawn farming was started in most of the study area and after that time a dramatically increase the change in cropping pattern as mention by the respondents in the study area. After stating Prawn farming a total of 14 cropping pattern were practiced. Among the 30 respondents in this study area, 8 respondents were not practiced the vegetables cultivation before prawn farming. Vegetables-vegetables cropping pattern was noticed by 18 respondents in gher's ail and 9 respondents in high land. Ricefish pattern was followed by 22 respondents in medium high land. In the study area of non- prawn farming at 1980 a total of 6 cropping patterns were practiced. At that time, among all the respondents (30), fallow-joli aus was practised by 14 respondents in low land and 8 respondents in medium high. Fallow-aus+aman was noticed to practised by 10 respondents in high land and 8 respondents in medium high land. Fallow-aman was noticed by 10 and 7 respondents in low land and medium high land.

In 2000s, in the study area of non-prawn farming, vegetablesvegetables was practiced 12 respondents in high land and 6 respondents in medium in high. Vegetables-fallow was noticed to be practiced 8 respondents in high land and 4 respondents in medium high land. Rice-rice was practiced by 14 respondents in low land and 5 respondents in medium high land. In the study area of nonprawn farming had a great significant role of vegetable cultivation and production. At present, vegetables-vegetables cropping pattern was practiced by 16 respondents in high land 8 respondents in medium high land. Vegetables-fallow was noticed to be practiced 8 respondents in high land and 5 respondents in medium high land. Rice -rice was practiced by 8 respondents in low land and 5 respondents in medium high land.

In the study area of shirmp farming in 1980 a total of 9 cropping patterns were practiced At that time, among all the respondents, fallow-aus+aman was noticed to practised by 12 respondents in high land and 10 respondents in medium high land. Fallow-joli aus was noticed to be practiced by 8 respondents in low land and 10 respondents in medium high land out of 30 respondent. Fallowaman was cited by 10 respondents in low land and 5 respondents in medium high land.

In the study area of shirmp farming in 2000s, vegetablesvegetables cropping pattern was practiced by 8 respondents in high land and 4 respondents in gher's ail. Vegetables-fallow was practiced 4 respondents in high land and 2 respondents in gher's ail. Vegetablesfruits were practiced by 1 respondent. Fallow-fish was practiced by 16 respondents in medium high land. Fish-fish was practiced by 8 respondents in medium high land. Fallow-fallow was noticed to be 23 respondents in gher's ail and 15 respondents in high land. In the study area shrimp farming during the study period a total of 10 cropping pattern was found. At that time, vegetables-vegetables was practiced by 12 respondents in high land and 6 respondents in gher's ail. Vegetables-fallow was practiced 6 respondents in high land and 2 respondents in gher's ail. Vegetables+fruits-fruits was followed by 4 respondents in high land. Fish-fish was practiced by 6 respondents in medium high land. Fallow-fallow was noticed to be 21 respondents in gher's ail and 2 respondents in medium high land and high land.

In the study area of non-shrimp farming in 1980 a total of 8 cropping patterns were practiced. At that time, among all the respondents, fallow-aus+aman was noticed to be practised by 10 respondents in high land and 8 respondents in medium high land out of 30 respondents. Fallow-joli aus were noticed by 12 respondents in low land and 6 respondents in medium high land. Fallow-aman was cited by 8 respondents in low land, 3 respondents in medium high land and 2 respondents in high land. In the study area of nonshrimp farming in 2000s, vegetables-vegetables cropping pattern was noticed by 15 respondents in high land and 7 respondents in medium high land. Vegetables-fallow was practiced by 8 respondents in high land and 4 respondents in medium high land. Vegetablesfruits were noticed by 3 respondents in high land and 2 respondents in medium high land. Vegetables-rice pattern was practiced by 4 respondents in medium high land and 6 respondents in high land. Rice-rice cropping pattern was noticed to be 15 respondents in low land and 6 respondents in medium high land. Rice-fallow cropping pattern was followed by 2 respondents in medium high land and 7 respondents in low land.

In the study area of non-shrimp farming, during the study period (vegetables-vegetables) cropping pattern was noticed by 14 respondents in high land and 6 respondents in medium high land. Vegetables-fallow was practiced by 10 respondents in high land and 4 respondents in medium high land. Vegetables-fruits were noticed by 4 respondents in high land and 1 respondent in medium high land. Rice-rice cropping pattern was noticed to be 17 respondents in low land and 5 respondents in medium high land.

\section{Causes of changing vegetables cropping pattern}

In the study area prawn farming, perception index (PI) of all causes of changing vegetable cropping pattern was calculated where it was highest in case of introduction of prawn farming (PI 73) i.e. the respondents perceived as the main cause of changing vegetable cropping pattern in the study area of prawn farming was introduction of prawn farming. On the other hand, increase of the demand of vegetable production, increase of vegetables yield in a unit area and increase of high yielding variety of vegetables were the moderate cause of changing vegetable cropping pattern and establishment of orchard, increase of salinity, demand of land for non agricultural process and natural calamities were the less cause of changing vegetable cropping pattern.

Perception index (PI) of all causes of changing vegetable cropping pattern was calculated where it was increase of the demand of vegetable production (PI 36), increase of vegetables yield in a unit 
area (PI 40) and increase of high yielding variety of vegetables (PI 34) i.e. the respondents perceived as the main cause of changing vegetable cropping pattern in the study area of non- prawn farming was increase of the demand of vegetable production, increase of vegetables yield in a unit area and increase of high yielding variety of vegetables. Perception index (PI) of all causes of changing vegetable cropping pattern was calculated where it was highest in case of increase of salinity (PI 60) i.e. the respondents perceived as the main cause of changing vegetable cropping pattern in the study area of shrimp farming was increase of salinity. On the other hand, increase of the demand of vegetable production, increase of vegetables yield in a unit area and increase of high yielding variety of vegetables were the moderate cause of changing vegetable cropping pattern (Figure $5)$.

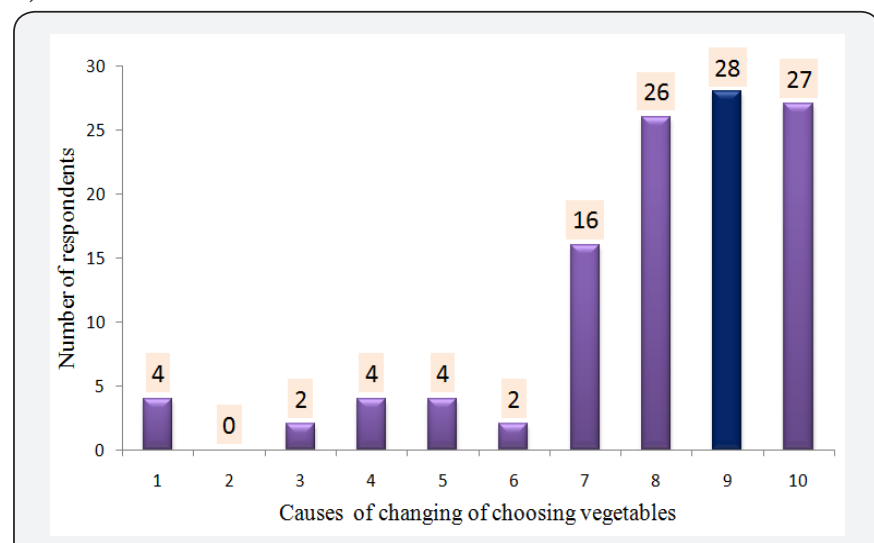

Figure 5: Causes of changing of choosing vegetables.

Note: 1 = Increase of salinity, 2 = Introduction of prawn farming, $3=$ Excess rainfall, $4=$ Drought, $5=$ Lack of essential irrigation water, 6 $=$ Natural calamities, $7=$ Change of food habit, $8=$ Availability of new variety, $9=$ high demand of vegetables and $10=$ Good market price

Perception index (PI) of all causes of changing vegetable cropping pattern was calculated where it was highest in case of natural calamities (PI 70) i.e. the respondents perceived as the main cause of changing vegetable cropping pattern in the study area of non-shrimp farming was natural calamities. On the other hand, increase of salinity, increase of the demand of vegetable production, increase of vegetables yield in a unit area and increase of high yielding variety of vegetables were the moderate cause of changing vegetable cropping pattern

\section{Conclusion}

Based on result and its logical interpretation the following conclusion may be drawn: Data were collected from 120 respondents, randomly selected from 4 types of areas. Majority of the respondents were middle aged had secondary level of educational qualification, small sized family, high experience in agriculture, high experience in vegetable cultivation, medium annual income, low organizational participation, low cosmopoliteness, low extension media contact, moderate total cultivable land, small suitable land for vegetable cultivation, small land under vegetable cultivation, no training, and medium knowledge.

A number of problems were identified in vegetable cultivation faced by the farmers in the study area. Among the 19 confronted problems unavailability of good quality seed, salinity, diseases and insect infestation were some of the major problems. Result indicates that majority of the respondents (60\%) fell in low problem confrontation category. Among the 11 selected characteristics of the respondents only cosmopoliteness and knowledge of vegetable cultivation showed a negative significant relationship. In case of shrimp farming area, total cultivable land area is higher than nonshrimp farming area, prawn farming and non-prawn farming but the average amount of suitable land for vegetable cultivation and land under vegetable cultivation in non-prawn farming area is higher than that of shrimp farming area, non-shrimp farming area and prawn farming area.

In case of non- shrimp farming area and shrimp farming area, diseases and insect infestation is higher than prawn farming area and non-prawn farming area. Among the selected 10 causes of changing of choosing vegetables, the most important was introduction of prawn farming for prawn farming area, increase of high demand of vegetables for non-prawn farming area, increase of salinity for shrimp farming area and non-shrimp farming area. There was a trend to increase in the total number of cropping patterns from 1980 s to present and showed a distinct figure of changing vegetables cropping patterns at different years. Among the selected 9 causes of changing vegetables cropping patterns, the most important was introduction of prawn farming for prawn farming area, increase of vegetables yield in a unit area for non-prawn farming area, increase of salinity for shrimp farming area and natural calamities for nonshrimp farming area.

\section{References}

1. CARE Bangladesh (1996) Pre-intervention survey of project participants for batch 1 gher farming households. Funded through Department for International Development.

2. CARE Bangladesh (1998) Pre-intervention survey of project participants for batch 2 gher farming households. Funded through Department for International Development.

3. CARE Bangladesh (2000) Pre-intervention survey of project participants for batch 3 gher farming households. Funded through Department for International Development

4. Glantz H, Qian (2010) Usable thoughts, Climate water and weather in the twenty-first century, United Nations University Press, Tokyo, Japan, pp. 133.

5. Rosenzweig C (1993) Climate Change and World Food Supply. Oxford University Press, India.

6. Schneider SH (1989) The Changing Climate. Scientific American 261(3):70-79.

7. Ezekiel M, K Fox (1959) Methods of correlation and regression analysis. John Wiley and Sons Inc., New York, USA. 
This work is licensed under Creative Commons Attribution 4.0 License

DOI:10.19080/PBSIJ.2017.04.555635
Your next submission with Juniper Publishers will reach you the below assets

- Quality Editorial service

- Swift Peer Review

- Reprints availability

- E-prints Service

- Manuscript Podcast for convenient understanding

- Global attainment for your research

- Manuscript accessibility in different formats

( Pdf, E-pub, Full Text, Audio)

- Unceasing customer service

Track the below URL for one-step submission https://juniperpublishers.com/online-submission.php 